\title{
ABORTION AND MORAL SAFETY
}

JAMES R. GREENWELL Scottsdale Community College

It is the contention of some Catholic theologians that in the absence of knowing whether the fetus is a person or not, the only morally safe thing to do is to assume that it is a person and not abort it. It will be the contention of this paper that this is not only not the only morally safe thing to do, but it has a rather low probability of being a correct thing to do at all.

\section{II}

If one has read the popular literature on the Catholic position, one might question putting it in the category of assuming that the fetus is a person. Is it not, one might ask, the position of the Church that it is certain that the fetus is a person? This is indeed the view that is commonly held, and there are some very definite statements by popes and others which seem to indicate it. Consider, for example, the 1930 statement of Pope Pius XI in his encyclical Casti Connubii:

We must also allude to another very serious crime, Venerable Brethern: that which attacks the life of the offspring while it is yet hidden in the womb of its mother. Some hold this to be permissible, and a matter to be left to the free choice of the mother or father; others hold it to be wrong only in the absence of very grave reasons, or what are called "indications," of the 
medical, social, or eugenic order ... As for the "medical and therapeutic indications," we have already said, Venerable Brethren, how deeply we feel for the mother whose fulfillment of her natural duty involves her in grave danger to health and even to life itself. But can any reason ever avail to excuse the direct killing of the innocent? For this is what is at stake. The infliction of death whether upon mother or upon child is against the commandment of God and the voice of nature: "Thou shalt not kill." The lives of both are equally sacred and no one, not even public authority, can ever have the right to destroy them. ${ }^{1}$

John T. Noonan points out, however, that while this is "the strongest and most comprehensive denunciation of abortion made by papal authority" it did not in fact constitute infallible teaching. ${ }^{2}$ Pope Pius XII reaffirmed this view in his 1951 address to the Italian Catholic Society of Midwives:

The baby in the maternal breast has the right to life immediately from God ... Hence there is no man, no human authority, no science, no medical, eugenic, social, economic or moral "indication" which can establish or grant a valid juridical ground for a direct deliberate disposition of an innocent human life, that is a disposition which looks to its destruction either as an end or as a means to another end perhaps in itself not illicit ... The baby, still not born, is a man in the same degree and for the same reason as the mother. ${ }^{3}$

1 Quoted in Daniel Callahan, Abortion: Law, Choice and Morality (New York: Macmillan, 1970), 414.

2 John T. Noonan (ed.), The Morality of Abortion, Legal and Historical Perspectives (Cambridge: Harvard University Press, 1970), 44.

3 In Ibid., 45. 
These statements are definite enough and set the stage for decision making at the practical level. However, there is still room for doubt about the Church position with respect to the personhood of the fetus. In the Catholic view, to be a person is equivalent to having a rational soul, which comes from God at the time of the event known as ensoulment. ${ }^{4}$ That there is still doubt as to the precise time of ensoulment, and hence when the fetus becomes a person, is evidenced by three considerations. First of all, if one examines the historical debate within the ranks of Catholic theologians and philosophers, he will find some saying that ensoulment takes place at fertilization, with others, including Thomas Aquinas, putting it at various times after fertilization. One thing is clear, however, and that is that there is neither a rational proof of any particular view nor a final consensus. ${ }^{5}$ The second consideration is the conspicuous absence of any revelation or "infallible" statement by a pope on the time of ensoulment. It is this factor which explains at least in part why the historical debate persisted without reaching agreement and, more significantly, why it is even continued into the deliberations of the latest of the great Church councils, Vatican II. This, the third consideration, refers to the situation which arose as the Council Commission dealt with the problems of marriage. The final position the Council took on abortion is expressed in its declaration: "Life from the moment of its conception is to be guarded with the greatest care. Abortion and infanticide are horrible crimes." When the question was raised as to the meaning of "conception" the Commission responded that the expression "from the moment of its conception" was not meant to determine the time of ensoulment. ${ }^{7}$ The situation is further confused by the Commission's

4 See Ibid., 51, 129.

${ }^{5}$ For surveys of this dispute see Callahan, Abortion: Law, Choice and Morality, 410-416, or Noonan, The Morality of Abortion, 7.46.

${ }^{6}$ In Walter Abbott (ed.), The Documents of Vatican II (New York: Corpus Books, 1966), 256.

7 See Noonan, The Morality of Abortion, 46. 
refusal to provide a precise definition of the term "abortus" when it was requested by three Council members. ${ }^{8}$ Father Bernard Haring, in his commissioned commentary on this part of the proceedings, explains this situation:

There are in fact marginal cases where no unanimity as yet prevails whether an "abortus" is involved or not, e.g. when the foetus certainly has no further prospect of life, while the mother's life can still be saved. It may be disputed whether in a particular case an attack on a human life is involved. ${ }^{9}$

In a later writing Father Haring puts it this way:

In the end it must be said that the question about the precise moment after which we are faced with a human being in the full sense is not yet settled and will probably not easily be determined. For this the Magisterium relies on the data of science and on philosophical thought. ${ }^{10}$

It seems clear, then, from these considerations that even though in practice the fetus is regarded as a person from conception on, there is no theoretical certainty of this. The rationale for making this assumption in practical matters is simply this: since the time of ensoulment is an event that cannot be verified either rationally or by revelation, the only morally safe procedure is to assume that ensoulment occurs at conception and behave accordingly. In other words, only if we assume that the newly-conceived fetus is a person, and

8 See Ibid.

9 In J. Vorgrimler (ed.), Commentary on the Documents of Vatican II (New York: Herder and Herder, 1967), Volume V, 242.

${ }_{10}$ Bernard Haring, "A Theological Evaluation," in Noonan, The Morality of Abortion, 129. 
because of that not abort it, can we be sure we are not killing a person in the act of abortion. As Father Haring puts it in his Commentary: "At all events it is clear that in case of doubt whether a real human life is yet present, nothing may be done which might possibly put an end to a human being." 11 In a later essay, Father Haring expressed the same idea in more religious language: "To interrupt such a process of growing life is not only to destroy a hope for human life but also to risk destruction of what is already created as a person made to the image and likeness of God." Whether this is indeed the only morally safe thing to do will be discussed later.

The doctrine of the double effect is the other mainstay of the Catholic position on abortion. It recognizes that an act can have both intended effects and unintended-but-foreseen effects. For example, a physician prescribes aspirin to reduce fever knowing that the aspirin will also damage the lining of the stomach. From the physician's point of view, the reduction of the fever is the intended effect, the stomach damage being an unintended-but-foreseen effect. The doctrine of the double effect states that the intended effect is to take priority in moral judgments. Consider the case of a pregnant woman whose life is threatened by the pregnancy. To save the mother requires aborting the fetus, but to abort the fetus, it must be killed. And, as we have seen, on the Catholic view the fetus is regarded as a person. So abortion involves the intentional killing of an innocent person, and that is always an immoral act. To avoid this immoral act, the mother is allowed to die. But in allowing her to die, no one intends her death. It is just an unintended-but-foreseen effect of not aborting the fetus. In aborting, there is the intention to kill, which is evil. In not aborting, there is no intention to harm the mother, so there is no evil on this alternative. Even though added.

11 Vorgrimler, Commentary on Documents of Vatican II, 242. Emphasis

12 Haring, "A Theological Evaluation," 131. Emphasis added. 
the end result is the same, i.e. a human life is lost, aborting is morally worse because it involves the intention to kill, where letting the mother die to keep from killing the fetus does not. The doctrine of the double effect would not be meaningful as a justification for letting the mother die to avoid killing the fetus if the Catholic did not recognize a prima facie obligation not to let the mother die. In the abortion situation there are two conflicting prima facie obligations. There is the obligation not to kill the fetus and the obligation not to let the mother die. The doctrine of the double effect is the Catholic's way of choosing between these conflicting obligations. Opponents of the doctrine of the double effect contend that it is the end result that takes priority, so killing the fetus and letting the mother die are morally on a par. If these two deaths are equal in moral priority, then other considerations must be appealed to in deciding what is morally right. As in the problem of the personhood of the fetus, none of the views about the validity of the doctrine of the double effect has gained general acceptance. This is another of the uncertainties that must be dealt with.

\section{III}

There is obvious disagreement, but are there principles the parties to the controversy would agree on? All parties would seem to agree to the prima facie validity of three moral principles, namely $(\mathrm{K})$ : It is wrong to knowingly kill an innocent person; (L): It is wrong to knowingly let an in. nocent person die; and (S) : It is wrong to knowingly let an innocent person suffer. The use of "knowingly" in each principle is meant to rule out accidents, events beyond the agent's control, etc. In other words, to knowingly kill a person or let him die or suffer means it was the agent's choice that this happen and he could have done otherwise if he had chosen to. The use of "innocent" in each principle is to rule out cases of just punishment, war, etc. For purposes of this paper, it will be assumed that if the fetus is a person, then it is an 
innocent person. While there is general agreement that these are prima facie valid moral principles, disagreements arise over which is to take priority in cases of conflict. The disagreement over which of $(\mathrm{K})$ or $(\mathrm{L})$ takes priority when they conflict is essentially the dispute over the validity of the doctrine of the double effect as it applies to abortion. The disagreement over which of $(\mathrm{K})$ or $(\mathrm{S})$ takes priority is essentially part of the long-running conflict over which is worse, death or suffering. To recap, there are these principles which all would accept as having prima facie validity:

$(\mathrm{K})$ : It is wrong to knowingly kill an innocent person.

(L): It is wrong to knowingly let an innocent person die.

(S): It is wrong to knowingly let an innocent person suffer.

In addition, there is the disagreement over the personhood of the fetus.

To establish a rationale that will be used in the ensuing discussion, consider this problem. A man is shot in such a way that the bullet has lodged in his spinal cord. After taking tests, X-rays, etc., the doctors conclude that there is no danger of infection or other organic problems if the bullet is left in place, and there is no danger to life if it is removed. However, due to its location in the spinal cord, there are some risks related to the man's use of his legs. The doctors tell the injured man that on the basis of their examinations, there are two courses of action open to them. They can either operate to remove the bullet and surgically repair the damage to the cord, or not operate but instead utilize a drug that will heal nerve tissue. They tell him that if he has the operation, his chance of complete recovery are 75 percent, and the chances of permanent paralysis are 25 percent. If he does not have the operation but depends on the drug, his chances of recovery are only 25 percent, while his chances of permanent paralysis are 75 percent. Under these circumstances, what is the most reasonable thing to do? Obviously, the most reasonable thing to do is to have the operation. By having 
the operation his chances of recovery are three out of four, whereas without the operation his chances of recovery are only one out of four. If the man chooses to have the operation and it turns out that he loses the use of his legs, his decision to have the operation was still the right decision given what he knew about the situation. The odds of his recovery were significantly greater on that alternative, so it was the reasonable thing to do, regardless of the eventual outcome. In the absence of complete knowledge, one has to go on the probabilities generated out of what is known. This rationale, which is the only reasonable one in light of the uncertainties, can be utilized in the abortion controversy.

\section{IV}

All anti-abortion groups except the Catholics hold that abortion to save the life of the mother is morally justified. The Catholic position is that abortion is not morally justified in this or any other case. Let us consider the situation which makes the Catholic position unique. It is the case where the mother's life is in peril, where a continuation of the pregnancy will result in her death, but an abortion will kill the fetus. In other words, either the mother or the fetus must die. How do we decide which it is to be? Given the facts of the case at hand, it will not be possible to abide by both principles (L) and (K). The only behavior consistent with (L), not letting the mother die, will involve a violation of $(\mathrm{K})$, the necessity to kill the fetus. Likewise, to behave according to $(\mathrm{K})$ and not kill the fetus will necessitate a violation of (L) in letting the mother die. Furthermore, while violating (K) will not cause additional suffering and hence a violation of (S), the violation of (L) certainly will violate (S) because of the physical and emotional suffering of the woman who is allowed to die, and of her survivors as well. So in this kind of case, (L) and (S) are consistent with each other, but both are inconsistent with the following of $(K)$. As noted above, while all would agree on the prima facie validity of 
$(\mathrm{K}),(\mathrm{L})$, and $(\mathrm{S})$, the disagreement arises over which takes priority in cases of conflict, such as the one under consideration. Unfortunately, no one has provided a generally accepted rationale showing which of these takes priority. This seems to remain an unresolved philosophical controversy.

Let us consider the possibilities in the case where either the mother or the fetus must die. Suppose the fetus is not a person. Then there is no conflict between $(\mathrm{K})$ and $(\mathrm{L})$, because to abort the non-person fetus would not be killing a person. So the fetus must be a person for $(K)$ to be a reason not to abort. Now suppose that the fetus is a person, but $(\mathrm{K})$ does not take priority. If $(\mathrm{K})$ and $(\mathrm{L})$ are morally equal, then (S) can be utilized to choose between them. Surely the mother will suffer if the abortion is not performed, so to choose $(\mathrm{K})$ and violate $(\mathrm{L})$ would be to violate $(\mathrm{S})$ as well. But to choose (L) would be to violate only $(K)$. If $(K)$ and $(L)$ have equal force, then the force of $(S)$ plays the decisive role. This shows that for abortion to be wrong, $(\mathrm{K})$ must take priority over (L) and the fetus must be a person. Perhaps the situation can be clarified by the following table, which shows the only four possible situations:

(1) If the fetus is a person and $(\mathrm{K})$ takes priority, then it would be wrong to abort. In this case $(K)$ is decisive.

(2) If the fetus is not a person and (K) takes priority, then abortion is called for. In this case, since the fetus is not a person, $(K)$ does not apply and $(L)$ is decisive.

(3) If the fetus is a person and $(\mathrm{K})$ does not take priority, then abortion is called for. In this case, since $(K)$ and $(\mathrm{L})$ are equal, $(\mathrm{S})$ becomes decisive.

(4) If the fetus is not a person and $(K)$ does not take priority, then abortion is called for. In this case (L) is decisive. 
It is clear that of the four possible cases, three call for abortion.

If we assume an equal likelihood for all the controversial factors, what is the situation in terms of probabilities? In other words, in the absence of knowing what is the right thing to do, what is the most reasonable thing to do? Given the alternatives above, what can we say? If the abortion is performed, the chances of its being morally right are 75 percent, while the chances of its being morally wrong are only 25 percent. If the abortion is not performed, the chances of that being morally right are only 25 percent, while the chances of that being wrong are 75 percent. Again, in the absence of knowing what is the right thing to do, what is the reasonable choice? If one chooses to abort, the odds that he does what is right are three out of four. If he chooses not to abort, they are only one out of four. As in the surgicalrisk case, it seems obvious that the reasonable thing to do is to opt for the abortion. Furthermore, even if future considerations show that it was a mistake, it was still the reasonable and moral thing to decide under the circumstances. And since it was the most reasonable and moral thing to do under the circumstances, the person choosing this way should be praised as having done the morally best thing in light of the available information.

The foregoing analysis has assumed that the doctrine of the double effect is as likely valid as not. However, if one rejects this doctrine that would eliminate case (1) as an alternative, leaving no case where it would be morally wrong to abort. If one takes the position that there is little likelihood that the fetus is a person early in the pregnancy, then if the abortion is done early and there are serious doubts about the doctrine of the double effect, it becomes extremely unlikely that any moral wrong is done in aborting to save the mother. If all the controversial factors are on equal footing, then the greatest probability of the correctness of the Catholic view is only 25 percent. Under these circumstances, 
it appears that the reasonable and hence morally safe thing to do is to abort.

\section{V}

It seems quite clear that given the uncertainties we have to work with, abortion is the morally right thing to do in the case we have discussed. It is important to remind ourselves that some of these things are indeed uncertainties. Despite all the attempts at determining the correct status of the fetus with respect to personhood, none seems to have won a logical victory. Some perhaps have an emotional appeal to some people, but that is quite different from having logical validity. Some people have made up their minds on the question of which is morally worse, killing, letting die, or allowing suffering, but no one has come up with a generally accepted rational justification for one of these over the others. In the absence of certainty on these key issues, we must settle for probability. And if that is the case, then the rationale proposed in this paper seems more valid than relying on emotion, intuition, authority, fate, luck, or any of the other things we frequently rely on in the place of reason.

Let us now give some consideration to some possible objections to this proposal. The rationale suggested here depends on there being about equal probability that the fetus is a person or that it is not, and about equal likelihood of the priority of $(\mathrm{K}),(\mathrm{L})$, and $(\mathrm{S})$. A critic might ask whether it is safe to assume an equal probability in these cases. With principles $(\mathrm{K}),(\mathrm{L})$, and $(\mathrm{S})$, in the absence of any rationale to establish some other level of priorities, would it be safe to assume anything other than an equal probability in each case? Suppose a person gave $(K)$ a much higher probability than $(\mathrm{S})$, not because of any logical rationale, but because abortion was emotionally abhorrent to him. If he then utilized this higher probability to show that abortion is morally wrong, he would simply be begging the question. This is one reason why it is too important to avoid emotionally-loaded 
language in discussing abortion. One favorite of the antiabortion groups is "slaughter of the unborn child." If one is swayed by this way of talking, he might more easily opt for $(\mathrm{K})$ and the personhood of the fetus. But if he cannot produce an argument to support these views, an argument that is logically prior to an evaluation of abortion, then he begs the question. While fallacious, this approach must be somewhat effective. Nearly any anti-abortion book or pamphlet one turns to will have a picture of a hospital garbage can full of aborted fetuses, fetuses chopped to pieces in the course of abortion, etc. The emotional impact of this is very great, but it is logically irrelevant unless it can be shown that these fetuses were persons and that killing them could not be justified on other grounds. But these are the things that have not yet been established. That abortion is sometimes gruesome is undeniable. That abortion is morally wrong is still an open question.

Another possible objection is that in life and death cases, probability is not good enough. Here we must be certain we do the right thing. But how is this to be managed when we must start with uncertainty in our basic considerations? What is this critic suggesting, that we put off making a decision until we can be sure? That we wait until some new data come along or some new arguments are generated? That would be fine if dangerous pregnancies would just stop until we can make up our minds with certainty. This is one of those situations that William James would have called a "forced option," a situation where refusing to decide is the same as deciding one way or the other. Suppose someone is faced with the need to decide whether an abortion should be performed, but he refuses to until he can decide with certainty. This is tantamount to deciding not to abort. Everything goes on, just as if he had consciously decided against the abortion. If we had certainty in these matters, things would surely be much simpler. But in the absence of this certainty, we must settle for what we can get, and that is probability. 
There are, no doubt, other objections that could be raised against this proposal, but the one objection that cannot be raised here, as it can in many pro-abortion arguments, is that this rationale depends on a callous disregard for the possible personhood of the fetus. This is given its due regard here, but the possibility of the falsity of this view is also given its due regard, and that is missing in many anti-abortion arguments. Perhaps in the future some new facts and arguments will be generated to resolve this issue. But if we are going to have a logically and morally respectable attitude toward abortion now, we must not pretend that uncertainties do not exist. The proposal in this paper has recognized these unsolved questions in offering a rationale to morally justify abortion, at least in the case where it saves the mother's life. In the absence of knowledge on the crucial factors relevant to abortion, reason and moral safety clearly seem to be on the side of aborting. 
La posición católica ante el aborto se deriva de dos supuestos básicos:

(1) El feto es una persona a partir de la fecundación.

(2) Es moralmente peor matar intencionalmente al feto que dejar morir a la madre por no matar al feto. Esta es la famosa doc. trina del doble efecto, tal y como se aplica al aborto.

Al leer la literatura publicada en la última década sobre el aborto, estas dos cuestiones parecen surgir como las áreas de mayor controversia. Es también evidente que ningún punto de vista acerca de las mismas ha obtenido una aceptación general. En lo que se refiere a la literatura contemporánea, nos enfrentamos a una incertidumbre respecto a estas cuestiones.

Se muestra que la posición católica dice que ante la ausencia de conocimiento acerca de la naturaleza del feto, la única posición moralmente segura es suponer que el feto es una persona y no abortarlo. La primera parte del artículo se dedica a mostrar que el católico está de hecho inseguro acerca de la naturaleza del feto y que se supone su carácter de persona para los efectos prácticos de decisión. A continuación se desarrolla un poco más la tesis católica con una breve discusión de la doctrina del doble efecto.

La parte más importante del artículo constituye un intento por mostrar que se puede aceptar la incertidumbre acerca del feto y la doctrina del doble efecto y, sin embargo, alcanzar una posición racional sobre la moralidad del aborto. Esto se obtiene considerando las diversas combinaciones posibles de los factores controvertidos y cuales combinaciones indican que el aborto es correcto y cuales que es incorrecto. Se aplican entonces probabilidades acerca de la corrección o incorrección del aborto, en el caso en que la continuación del embarazo amenaza la vida de la madre. La tesis que propone el artículo es la de que en ausencia de certidumbre sobre las cuestiones más importantes, podemos tomar una decisión con base en las probabilidades. Utilizando este procedimiento, se muestra que el aborto hecho para salvar a la madre tiene mayores probabilidades de corrección moral que el no abortar, por lo que es la postura moralmente segura.

(Resumen de James R. Greenwell) 